Chapter 4

\title{
Interaction between Erythropoiesis and Iron Metabolism in Human $\beta$-thalassemia - Recent Advances and New Therapeutic Approaches
}

\author{
Nadia Maria Sposi \\ Additional information is available at the end of the chapter \\ http://dx.doi.org/10.5772/61716
}

\begin{abstract}
For its frequency and severity $\beta$-thalassemia represents a significant health problem in various areas of the world. Progressive iron overload is a common complication of hemoglobinopathies and represents a major cause of morbidity and premature mortality in patients with $\beta$-thalassemia.The discovery of hepcidin and its role in iron homeostasis has revolutionized our understanding of the pathogenesis of iron overload and iron-restricted anemias, stimulating the development of new diagnostic and therapeutic modalities for these disorders. However, little is known about the relationship among ineffective erythropoiesis, the role of iron-regulatory genes, and tissue iron distribution in $\beta$-thalassemia. The chapter describes evidences for these relationships and discusses how recent discoveries on iron metabolism and erythropoiesis could lead to new therapeutic approaches and better clinical care of these diseases.
\end{abstract}

Keywords: Thalassemia, Erythropoiesis, Iron Metabolism, Hepcidin, Ferroportin

\section{Introduction}

In recent years there has been important advancement in our knowledge of iron metabolism regulation that also has implications for understanding the pathophysiology of some human disorders such as beta-thalassemia ( $\beta$-thalassemia) and other overload diseases. Progressive iron overload has become a major cause of morbidity and premature mortality in patients with $\beta$-thalassemia. However, little is known about the relationship among ineffective erythropoi- 
esis, the role of iron-regulatory genes, and tissue iron distribution in $\beta$-thalassemia. Our understanding of the pathogenesis of iron-restricted anemias and iron overload has been revolutionized by the discovery of hepcidin and its role in iron homeostasis, stimulating the development of new diagnostic and therapeutic modalities for these disorders. Further work is required to understand the mechanisms of hepcidin regulation by iron and erythroid activity and to understand the structure, the transport function and the complex regulation of the hepcidin receptor ferroportin. The chapter describes evidences for these relationships and discusses how recent discoveries on iron metabolism and erythropoiesis could lead to new therapeutic approaches and better clinical care of these diseases, thereby yelding a much better quality of life for patients suffering from iron disorders and anemias.

\section{Overall view on $\beta$-thalassemia}

$\beta$-thalassemias are a group of hereditary blood disorders characterized by the reduced $\left(\beta^{+}\right.$or $\beta^{++}$) or absent $\left(\beta^{0}\right)$ synthesis of the $\beta$-globin chains of the hemoglobin $(\mathrm{Hb})$ tetramer. The term thalassemia is derived from the Greek words thalassa (sea) and haima (blood) and is one of the most common autosomal recessive disorders worldwide. $\beta$-thalassemia is prevalent in Mediterranean countries, the Middle East, Central Asia, Far East, as well as countries along the Americas (Fig.1). The highest incidences are reported in Cyprus (14\%), Sardinia (12\%) and South-East Asia [1-3]. The high gene frequency of $\beta$-thalassemia in these regions is most likely related to the selective pressure from Plasmodium falciparum malaria [1-2]. Carriers of $\beta-$ thalassemia are indeed relatively protected against the invasion of Plasmodium falciparum. However, because of population migration and intermarriage between different ethnic groups, $\beta$-thalassemia is, at present, also common in Northern Europe, North and South America,the Caribbean and Australia [4]. The inability to synthesize $\beta$-globin chains results in an excess of $\alpha$-globin chains that precipitate in red cell precursors and cause abnormal cell maturation and their premature destruction in the bone marrow (ineffective erythropoiesis). Red cells that survive to reach the peripheral circulation are prematurely destroyed in the spleen. The clinical manifestations of $\beta$-thalassemia are extremely diverse, spanning a broad spectrum from the transfusion-dependent state of thalassemia major (TM) to the asymptomatic state of heterozygous carriers for $\beta^{\circ}$ or $\beta^{+}$(thalassemia trait).

$\beta$-thalassemias can be classificated into:

- Thalassemia major

- Thalassemia intermedia

- Thalassemia minor

$\beta$-thalassemia with associated $\mathrm{Hb}$ anomalies:

- $\mathrm{Hb} \mathrm{C} / \beta$-thalassemia

- $\mathrm{Hb} \mathrm{E} / \beta$-thalassemia

- $\mathrm{Hb} \mathrm{S/ \beta}$-thalassemia 




Figure 1. Thalassemia distribution and most common $\beta$-thalassemia mutations in different countries.

Hereditary persistence of fetal $\mathrm{Hb}$ and $\beta$-thalassemias

Autosomal dominant forms

$\beta$-thalassemia associated with other manifestations:

- $\beta$-thalassemia- tricothiodystrophy

- $\mathrm{x}$-linked thrombocytopenia with thalassemia

Many different mutations cause $\beta$-thalassemia. They are inherited in a multitude of genetic combinations responsible for a heterogeneous group of clinical syndromes. Thalassemia minor, also known as $\beta$-thalassemia trait or heterozygous $\beta$-thalassemia, is caused by the presence of a single $\beta$-thalassemic mutation and a normal $\beta$-globin gene on the other chromosome. Microcytosis, hypochromia, increased $\mathrm{HbA} 2$ level and mild or minimal anemia are the characteristic hematological features of beta-thalassemia carriers. The $\beta$-thalassemia carrier state is clinically asymptomatic and needs no specific treatment. Thalassemia major, also known as Cooley's anemia or homozygous $\beta$-thalassemia, is a clinically severe disorder that results from the inheritance of two $\beta$-thalassemia alleles, one on each copy of chromosome 11. Patients have a severe microcytic and hypochromic anemia, associated with increased number of red blood cells and low mean corpuscular volume (MCV) and mean corpuscular $\mathrm{Hb}(\mathrm{MCH})$. Peripheral blood smear shows, in addition to microcytosis and hypochromia, anisocytosis, poikilocytosis and nucleated red blood cells (e.g., erythroblasts) [4]. The anemia of thalassemia major is so severe that chronic blood transfusions are usually required. Repeated transfusions and increased iron absorption lead to iron deposition in many organs (liver, endocrine tissues, heart) and ultimately death unless chelation therapy is used [5]. Hemoglobin analysis shows mainly $\mathrm{HbF}$ plus a small amount of $\mathrm{HbA}_{2}$ in $\beta^{0}$ homozygotes, but insufficient to compensate 
for the loss of $\mathrm{HbA}$, and the $\mathrm{Hb}$ level remains $<5 \mathrm{~g} / \mathrm{dL}$ [5]. Most $\beta^{+}$homozygotes and $\beta^{+} \beta^{0}$ compound heterozygotes also have thalassemia major. HbF remains the predominant hemoglobin but with variable amounts of $\mathrm{HbA}$ depending on the specific $\beta^{+}$thalassemia allele [5]. The term $\beta$-thalassemia intermedia (TI) is applied to a less severe clinical phenotype in which significant anemia occurs but chronic transfusion therapy is not absolutely required. Patients show a markedly heterogeneous hematological picture, ranging in severity from that of the $\beta$-thalassemia carrier state to that of thalassemia major [4]. Most patients affected by thalassemia intermedia are homozygotes or compound heterozygotes for $\beta$-thalassemia, meaning that both $\beta$-globin loci are affected. Less commonly, only a single $\beta$-globin locus is affected, the other being completely normal. The mild clinical characteristics of TI compared with thalassemia major result primarily from the inheritance of two $\beta$-thalassemia mutations, one mild and one severe; the inheritance of two mild mutations or, occasionally, the inheritance of complex combinations, such as two $\beta$-thalassemia mutations co-inherited with heterozygous $\alpha$-thalassemia. In this last form, known as $\alpha \beta$-thalassemia, the $\alpha$-thalassemia allele reduces the burden of unpaired $\alpha$-globin chains [6-9]. Table 1 shows some of the commonest causes of thalassemia intermedia. The $\beta$-globin gene maps in the short arm of chromosome 11 an $80 \mathrm{~Kb}$ region also containing the $\delta$ globin gene, the embryonic $\varepsilon$ gene, the fetal $A \gamma$ and $G \gamma$ gene [4]. The five functional globin genes are arranged in the order of their developmental expression (Fig 2) [4]. The $\beta$-globin gene is regulated by an adjacent $5^{\prime}$ promoter in which a Tata, CAAT and duplicated CACC boxes are located [4]. A major regulatory region, containing also a strong enhancer, maps $50 \mathrm{~Kb}$ from the $\beta$-globin gene. This locus control region (LCR) contains four (HS-1 to HS-4) erythroid specific DNAse hypersensitive sites $\left(\mathrm{HS}_{\mathrm{S}}\right.$ ) containing a variety of binding sites for erythroid transcription factors [4,10-11]. The LCR together with the proximal cis-element transcription factors controls the developmental stage specific expression of genes: from $\varepsilon$ to $\gamma$, and from $\gamma$ to $\beta$ and $\delta$ during development from embryo to adult. Very early in gestation there is a switch from $\varepsilon$ to $\gamma$-globin production. The fetal hemoglobin $(\mathrm{HbF})$ reaches a plateau after 10 - weeks and remains high until 2- years after birth, when it begins to decrease to $0.5-1 \%$ of total hemoglobin in adult red blood cells. The $\beta$-globin chain synthesis starts at 30-35- weeks of gestation contributing at this time to $10 \%$ of the total hemoglobin. After birth it increases to $97 \%$ forming the adult hemoglobin $\mathrm{HbA}$. The other type of adult hemoglobin is the $\mathrm{HbA}_{2}$ formed by $\delta$ chains whose synthesis begins at the 7 thmonth of gestation reaching $2-3 \%$ in adult life (Fig 2) [12]. Forms of $\beta$-thalassemia arise from mutations that affect every step in the pathway of globin gene expression: transcription, processing of the mRNA precursor, translation of mature mRNA, and post-translational integrity of the $\beta$-polipeptide chain [13]. Over 200 different thalassemia alleles of the $\beta$-globin gene have been reported; the vast majority are caused by point mutations within the gene or its immediate flanking sequences. The distribution of alleles is highly variable from one population to another but within each population there are only a few alleles that are common (Fig 1) [5]. While most alleles behave as Mendelian recessives, there are variants that cause a disease phenotype even when present in a single copy. These act in a dominant negative fashion and are referred to as dominantly inherited $\beta$-thalassemias [5]. Conditions with $\mathrm{HbF}$ production high enough to give good compensation are known as hereditary persistence of foetal hemoglobin $(\mathrm{HPFH})$ and homozygotes are clinically unaffected while compound heterozygotes with $\beta$-thalassemia are very mild [5]. Fetal hemoglobin is a much more common and major modifier of disease severity in individuals with $\beta$-thalassemia. In normal individ- 
uals only $5-8 \%$ of red cells, called $\mathrm{F}$ cells, contains $\mathrm{HbF}$, amounting to $5-20 \%$ of the total hemoglobin in those cells [14,15]. In the context of a severe deficiency of $\beta$-globin synthesis, even the low levels of $\gamma$-globin in F_cells reduce the relative excess of a $\alpha$-globin and provide a potent selective survival advantage for cells making $\mathrm{HbF}$ in the context of the ineffective erythropoiesis characteristic of the most severe forms of $\beta$-thalassemia [14]. Some $\beta$-thalassemia mutations increase " per se" the $\gamma$-globin gene synthesis, i.e. deletion and non deletion $\delta \beta$-thalassemia or deletions of the 5 ' region of the beta-globin gene. Also mutations associated with deletion and non-deletion HPFH linked to the $\beta$-globin gene cluster are characterized by increasing $\mathrm{HbF}$ production. Recently, the genome-wide association studies (GWAS) revealed genetic elements not linked to the $\beta$-globin gene cluster, able to modify the severity of the homozygous $\beta^{0}$ - thalassemia. In particular, two new regulatory pathways leading to increased $\gamma$-globin expression have been identified, i.e. BCL11A and HBS1L-MYB. Both seem to act directly or indirectly affecting the production of repressor proteins that specifically target the $\gamma$-globin genes [16]. The clinical phenotype of homozygous $\beta$-thalassemia may also be modified by co-inheritance of other genetic variants mapping outside the globin clusters:. the presence of $(\mathrm{TA})_{7}$ polymorphism in the promoter region of the uridine diphosphate-glucuronosyltransferase gene is a risk factor for the development of cholelitiasis in thalassemia major and intermedia patients; the apolipoprotein E $\varepsilon 4$ allele and some HLA haplotypes, which seem to be genetic risk factors for left ventricular failure in homozygous beta-thalassemia; a polymorphism in glutathione-S transferase M1 gene has been associated with an increased risk of heart iron overload in thalassemia major [1]. The expression of $\beta$-globin genes is also affected by point mutations belonging to three different categories: mutations of promoter and 5'UTR lead to defective $\beta$-gene transcription; mutations of splice-junction and 3'UTR affect mRNA processing; and non-sense, frameshift, and initiation codon mutations result in abnormal mRNA translation. Phatophysiology of $\beta$-thalassemia can be summarized as follows: the reduced amount or absence of $\beta$-globin chains result in a relative excess of unbound $\alpha$-globin chains that precipitate in erythroid precursors in the bone marrow. Aggregation, denaturation and degradation of these chains lead to the formation of insoluble precipitates as well as hemichromes, which damage cell membranes leading to their premature death and hence to ineffective erythropoiesis. Red cells hemolysis within the circulation and membrane binding of IgG and C3 causes loss of red cells in the spleen. The resulting anemia leads to diminished tissue oxygenation, an increase in erythropoietin levels and bone marrow stimulation and expansion causing skeletal deformities and osteopenia. Substances released from damaged red cells increase iron absorption contributing to iron overload [14]. Diagnosis of $\beta$-thalassemia is based on hematologic and molecular genetic testing. Differential diagnosis is usually straightforward but may include genetic sideroblastic anemias, congenital dyserythropoietic anemias and other conditions with high levels of HbF. Genetic counseling is recommended and prenatal diagnosis may be offered. Prognosis of thalassemia minor subjects is excellent. Individuals with thalassemia intermedia may require splenectomy, folic acid supplementation, treatment of extramedullary erythropoietic masses and leg ulcers, prevention and therapy of thromboembolic events. Patients with thalassemia intermedia who do not usually have severe hemosiderosis are less prone to cardiac problems [1,17]. The prognosis of $\beta$-thalassemia major was very grim before there was any treatment available. With no treatment, the natural history was for death by age five from infections and cachexia [1]. Treatment of thalassemia major includes regular RBC transfusions, iron chelation and 
management of secondary complications of iron overload. In some circumstances, spleen removal may be required. However, many transfusion-dependent patients continued to develop progressive accumulation of iron. This can lead to tissue damage and eventually death, particularly from cardiac disease. The introduction of new iron chelators and chelation regimes associated to the monitoring of myocardial siderosis and cardiac function have converted a once universally fatal disease to a chronic illness. Children treated with chelators since a very young age are expected to have an excellent long-term prognosis [18-19]. Stem cell transplantation is at present the only available definitive cure for patients with thalassemia major but still has a substantial risk of mortality and morbidity. Umbelical cord-blood transplantations have had limited success in the treatment of $\beta$-thalassemia because of the large numbers required to sustain hematopoiesis. LV-mediated gene therapy for the $\beta$ hemoglobinopathies is now entering early-phase clinical trials and offers great promise. Even if these approaches are successful, such molecular therapies are likely to be expensive and might not be immediately applied to most patients in low-income countries. Much evidence from clinical genetic studies shows that the induction of $\gamma$-globin chain synthesis by gene transduction or pharmacological agents would have substantial clinical benefits in patients with $\beta$-thalassemia [12,20-26]. However the results obtained have not been sufficiently encouraging to develop large-scale trials [12,24-26]. Furthermore, these agents have several effects, and how any of these drugs work to increase expression of $\mathrm{HbF}$ is not fully understood. Recently pre-clinical evidence of potentially new approaches to treating patients with TI and TM has been reported. The evidence for using Tf, hepcidin agonists and JAK2 inhibitors is discussed later in this chapter.

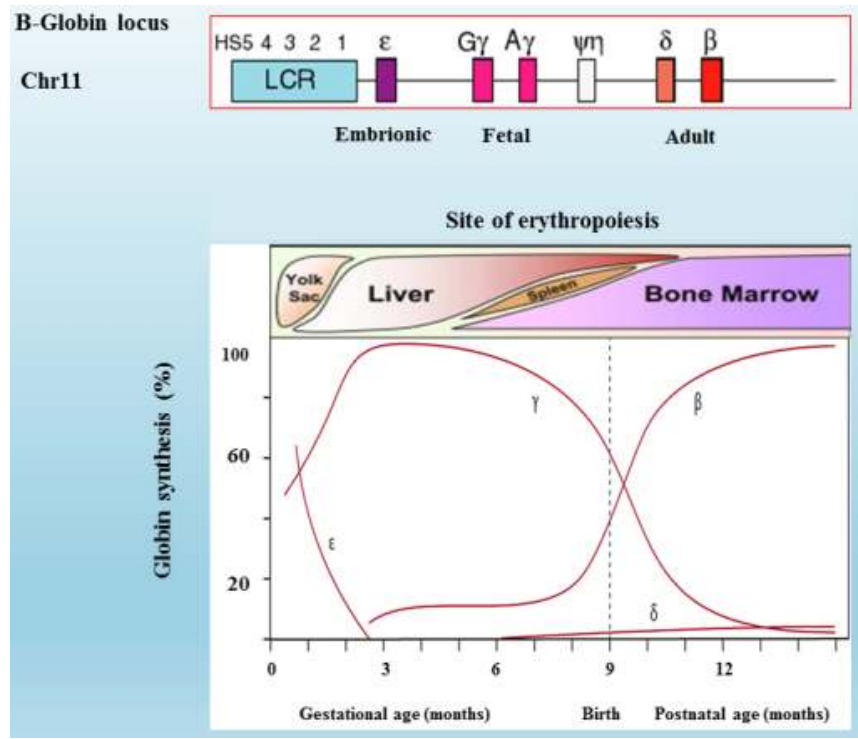

Figure 2. In the top panel, the organization of human $\beta$-globin locus is shown. Upstream DNase I hypersensitive sites (HS) within the locus control region (LCR) are displayed. The bottom panel shows the fetal-to-adult hemoglobin switch. This illustration depicts the normal timing of the developmental hemoglobin switches in humans. This figure is adapted from [4] and [12]. 


\begin{tabular}{ll}
\hline & $\cdot$ Homozygosity for silent or mild $\beta$-thal \\
Mild deficit in $\beta$-chain production & $\cdot$ Compound heterozygosity for severe and mild $\beta$-thal \\
& $\cdot$ HbE/ $\beta$-thal \\
& $\cdot$ Heterozygous $\beta$-thal with $\alpha \alpha \alpha$ or $\alpha \alpha \alpha \alpha$ \\
\hline \multirow{2}{*}{ Reduced $\alpha$-chain excess } & $\cdot$ Homozygous $\beta^{\circ}$ or $\beta^{+}$thal with 2 or $3 \alpha$ gene deletions \\
& $\cdot$ Homozygous $\beta^{\circ}$ or $\beta^{+}$thal with non deletion $\alpha$-thal \\
& $\cdot$ Homozygous $\beta^{+}$thal with 1 or $2 \alpha$ gene deletions \\
\hline Increased $\gamma$-chain synthesis & $\cdot$ Homozygous $(\delta \beta)^{\circ}$-thal or $(\mathrm{A} \gamma \delta \beta)^{\circ}$-thal \\
& $\cdot$ Homozygosity for Hb Lepore \\
& $\cdot$ Compound heterozygosity for Hb Lepore/ $\beta$-thal \\
\hline Dominant $\beta$-thalassemia & $\cdot$ Compound heterozygosity for severe $\beta$-thal and HPFH \\
\hline
\end{tabular}

Table 1. The commonest causes of thalassemia intermedia

\section{Overall view on erythropoiesis}

The production of red blood cells, known as erythropoiesis, is a developmental system fundamentally under genetic control that involves differentiation of pluripotent hematopoietic stem cells (HSCs) and early multipotent progenitors (MPP) in erythroblasts and mature erythrocytes. Human erythroid differentiation is also regulated and modulated by the interaction of humoral, cellular and molecular processes [27-30]. The erythroid progenitor cell compartment contains the early erythroid progenitors (BFU-E, burst-forming units-erythroid), which differentiate into late colony-forming units erythroid (CFU-E) and proerythroblasts. BFU-E represent the earliest progenitors committed exclusively to erythroid maturation and a quiescent reserve because only $10 \%$ to $20 \%$ are in cycle at any given time. CFU-E is more differentiated than BFU-E and most of these progenitors (60-80\%) are already in cycle. The earliest recognizable erythroid cells are the proerythroblasts, which differentiate in basophilic erythroblasts, followed by polychromatophilic and orthochromatic erythroblasts. After the last mitotic division, the inactive dense nucleus of the orthochromatic erythroblast is extruded and the resulting mature enucleated cell is a reticulocyte. Mature red blood cells are biconcave disks without mithocondria and other organelles, but with a very high concentration of hemoglobin able to bind and deliver O2 [29, for an exhaustive review see 31-37]. Fig. 3 schematically represents the pathway of erythropoiesis from progenitors to mature cells. The blood has a very important role in the functions of the organism from the earliest moments of its development, so that during embryonic life the various stages of the hematopoietic process alternate at different sites according to the different stages of development [38-39]. The embryonic $\rightarrow$ fetal hematopoiesis is characterized by three fundamental periods of activity progressively involving the yolk sac, liver and bone marrow. The first period, during which hematopoiesis is localized at the yolk sac, begins between the 14th and 19th days of embryonic life and continues until the completion of the 3rd month [38-39]. Starting from the third month, the second phase of hematopoiesis takes place in the liver where it reaches its maximum during the 3rd-4th month and remains active until a few weeks before birth, when the definitive 
hematopoiesis (third phase) is concentrated only in the bone marrow and it will continue throughout adult life [38]. In this system of hematopoietic differentiation four compartments may be identified: stem cells, the progenitors (cellular compartments), precursors, and mature elements of circulating blood (maturation compartments) [39]. Hematopoietic stem cells are characterized by the ability to self-renew (i.e., to generate other totipotent stem cells) and differentiate into hematopoietic progenitor cells. Stem cells also show the important property to remain for a long time in a state of quiescence during adult life [36-37,39-40]. Primitive progenitors are able to generate blast colonies (CFU-B), the progenitors of high proliferative potential (HPP-CFC, colony-forming cells that power high-proliferative), and finally the multipotent progenitors that are still capable of generating mixed colonies, belonging to the different types of hematopoietic differentiation: erythroid, granulocyte, monocyte, and megakaryocytic (the CFU-GEMM) [37,41-42]. Mature progenitors are committed to the differentiation towards a singular hematopoietic lineage and are functionally defined as early burst forming units (BFUs) or more differentiated colony forming units (CFUs): erythroid progenitors are BFU-E and CFU-E; granulocytic-macrophagic progenitors are CFU-GM, CFUG and CFU-M; finally megakaryocitc progenitors are BFU-Mk and CFU-Mk [37,41-42]. The proliferation, maturation and differentiation of hematopoietic stem cells and progenitors are regulated by the interaction of several hematopoietic growth factors with specific membrane receptors and the consequent activation of the appropriate signal transduction pathways. These factors are also known as colony stimulating factors (CSFs), interleukins (ILs), or hemopoietins and are produced from accessory cells such as macrophages, lymphocytes, fibroblasts, and endothelial cells. They can be classified into three categories, depending on their mechanism of action during hemopoietic differentiation (Fig.3) [34,39]. In the first category are grow th factors acting at the earliest stages of hematopoiesis, i.e. the stem cell factor (SCF) [43], FLT-3 ligand (FL) [44,45], the basic fibroblast growth factor (bFGF) [46,47], and interleukin-6 (IL-6) [48]. IL-3 and GM-CSF, growth factors acting as multilineage, belong to the second category and are able to stimulate primitive progenitors to proliferate and differentiate into all hematopoietic lineage [49]. The third category includes the unilineage growth factors acting on progenitors already committed and promoting the production of mature cells in the circulating blood, i.e. erythropoietin (EPO) [50-51], the granulocytic growth factor (GCSF) [52], monocytic growth factor (M-CSF) [53], and thrombopoietin (TPO) [54]. During hematopoietic differentiation, the maintenance of iron homeostasis is essential for erythrocytes and macrophages. Erythroid cells need to incorporate very high amounts of iron to support the continued synthesis of heme and hemoglobin, while the macrophage cells play a key role in the storage and recycling of iron [29,39,55-56]. During the differentiation of erythroid progenitors towards mature red cells the following morphologically recognizable stages can be distinguished: 1 ) the earlier stage of proerythroblast, that presents a nucleus relatively large in respect to the cytoplasm, and one or two nucleoli; 2) the more advanced basophilic erythroblast, characterized by a reduced cellular diameter, a nuclear volume reduced more rapidly than the cytoplasm, and a cytoplasm uniformly basophilic; 3) the polychromatophilic erythroblast, that shows the initial condensation of the nucleus, nucleoli no longer visible and the cytoplasm with acidophilic areas; 4) the orthochromatic erythroblast, with a nucleus:cytoplasm ratio of approximately 1:4, nucleus darker and subject to pyknotic degeneration, and cytoplasm slightly pink as a consequence of the progressive increase in hemoglobin concentration; and finally 5) the reticulocyte that has lost its nucleus and, through the complete 
degradation of ribosomes and mitochondria, proceeds to the transformation in mature erythrocyte [34,37,39,42,57-58]. In adult mammalian bone marrow erythroblasts are always associated with the erythroblastic islets that represent the drive amplification stage anatomy of erythropoiesis and consists of 1 or 2 histiocytic crown cells surrounded by erythroblasts at all stages of maturation. The histiocytes have thin cytoplasmic extensions that insert between erythroblasts suggesting that factors of nutrition can be provided by the histiocytic cell, centrally located, to the peripheral maturing erythroblasts $[37,39,42]$. The most important factor involved in the control of erythropoiesis is erythropoietin, but other substances, particularly hormones, contribute to the regulation of this process [59]. Transferrin comes out from the bone marrow sinusoids using ample fenestrature exits, and binds to surface receptors carried by erythroblasts. The iron transferred from transferrin and transported to the mitochondria is reduced from $\mathrm{Fe} 3+$ to $\mathrm{Fe} 2+$ and then inserted into protoporphyrin IX by tetrapyrroles heme synthetase (Heme Synthetase HS) for the synthesis of heme [39,55-56,59]. The reticuloendothelial system is a functional unit that includes cells having heterogeneous histologically different identities and a widespread distribution throughout the body, which share the common property of phagocytic activity, e.g. endothelial cells of blood capillaries of liver, spleen, bone marrow and lymph-nodes, tissue and circulating macrophages [59-60].The reticuloendothelial system is the most important source of iron that enters the blood compartment. The flow of iron from the reticuloendothelial plasma is unidirectional, as the reticuloendothelial cells are not able to pick up the metal from transferrin, but receive only hemoglobin or ferritin iron [59-60]. Senescent erythrocytes at the end of their life (approximately 120-days) are phagocytized by endothelial cells and represent the largest source of iron entering the reticuloendothelial system. About $85 \%$ of the iron that enters the reticuloendothelial cells is promptly transferred to plasma transferrin and the remaining $15 \%$ is stored as intracellular ferritin, and transferred to plasma much more slowly [39,42,59-60]. The production of red blood cells is regulated by a complex network of transcription factors, among which GATA-1 is considered the master gene of erythropoiesis. GATA-1 positively regulates specific erythroid genes such as erythropoietin receptor (EpoR), glycophorin (GpA), and globin chains and, together with the transcription factor STAT5, induces the expression of the antiapoptotic protein Bcl-xL (Fig.3 and Table 2) [61-63]. The program of erythroid proliferation and differentiation must be positively and negatively regulated to ensure a continuous but tightly controlled production of red blood cells. Erythropoiesis is positively controlled by the combined effect of two major cytokinesis, SCF and Epo. SCF is produced by stromal cells and exerts its effects on erythroid cells mainly during the early and late stages of differentiation of erythroid progenitors, and may act also on immature erythroid precursors. Epo is responsible for the finely tuned homeostatic control of erythrocyte numbers by tissue oxygenation. Epo exerts its effect by stimulating Epo-R. The binding of Epo with the EpoR induces a conformational change that activates the pre-bound, cytoplasmic tyrosine kinase JAK2. The activation of JAK2 induces multiple signaling pathways involving P13 kinase, Akt and STAT5, which prevent apoptosis, supporting erythroid progenitors proliferation and differentiation (Fig.3) [63-66]. However, a negative control of erythropoiesis is clearly required at several levels to avoid overproduction of erythroid cells and polycythemia, which may lead to hyperviscosity and ultimately to thrombosis. The negative regulation is mainly due to apoptosis, a fundamental cellular mechanism allowing clearance of unneeded or potentially dangerous cells. Caspases appear to play a critical role in erythroid apoptotic programs. Caspases belong to a 
family of cysteine-dependent and aspartate-specific proteases and, in particular, two classes are described: initiators (caspase- 8 and -9 ) and effectors (caspase- 3 and -7 ). Caspase- 8 is activated by the death receptor pathway and caspase- 9 by events causing intracellular damages and alterations in mitochondrial membrane potential. Activated caspase -8 and caspase -9 then activate effectors such as caspase -3 that cleaves GATA-1, Tal-1, and proteins involved in cytoplasm, nucleus, and DNA integrity, which allow the cell death program to occur. Death receptors of the TNF receptor (TNF-R) superfamilies (Fas-L, TNF- $\alpha$, TRAIL) activate the extrinsic apoptotic pathway. Some studies suggest the existence of a negative regulatory feedback operating at low Epo level in a paracrine pathway. Briefly the control of mature red blood cell production may be summarized as follow: at low doses of Epo, cells die by apoptosis, at intermediate doses, cells are arrested in their maturation or enter a program of apoptosis, depending on the number of mature erythroblasts in the bone marrow, and at high doses of Epo, erythroid progenitors and precursors pursue their maturation independently of the number of mature erythroid precursors [63,67-68]. In summary, the emerging picture is that certain genes, such as SCL, are absolutely required for hematopoietic development, whereas others, such as GATA-2, c-Myb, CBF and some downstream signal transducing molecules, such as Jack 2 and STAT5, are responsible for expansion and maintenance of a normal pool of fetal liver and adult hematopoietic progenitors. The participation of many of these molecules in multicomponent molecular complexes with protein/protein and protein/DNA interactions (e.g., LMO2/Lmbd1/SCL/GATA), during the early, proliferative stages of hematopoiesis may underlie their role in the proliferation and maintenance of immature progenitor/precursor pools in erythropoiesis [69]. Other genes such as GATA1, its partner FOG1, and EKLF are necessary to direct high levels of function of erythroid-specific genes in cells already committed to terminal differentiation. Thus, a hierarchical requirement in the expression of specific regulators during early versus late erythroid differentiation or during embryonic versus fetal liver/adult erythropoiesis is established.

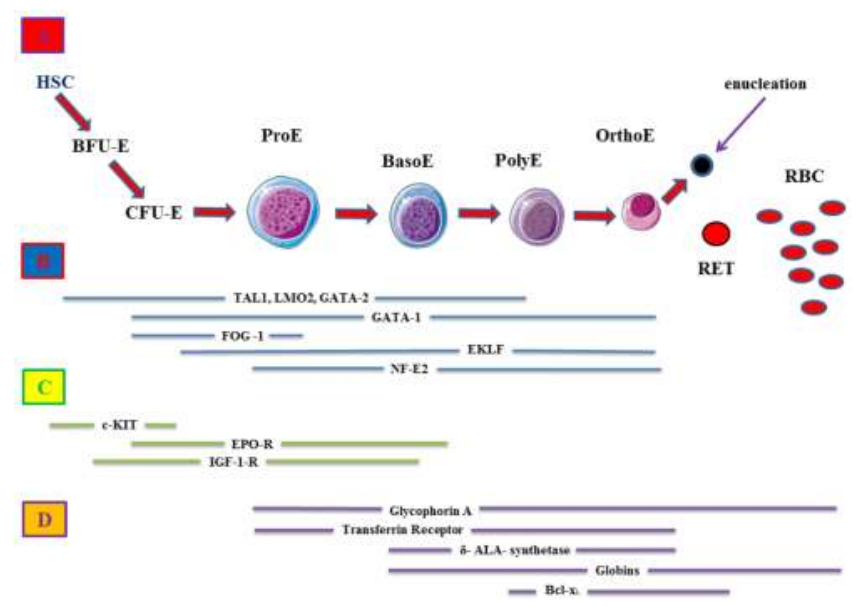

Figure 3. A) Pathway of the erythropoiesis from progenitors to mature cells. Different stages are indicated: hematopoietic stem cell (HSC), burst-forming unit erythroid (BFU-E), colony-forming unit erythroid (CFU-E), proerythroblast (ProE), basophylic (BasoE), polychromatic (PolyE), and orthochromatic erythroblast (OrthoE). B) Erythroid transcrip- 
tion factors: basic helix-loop-helix factor (TAL1); Lim-domain partner of TAL1 (LMO2); zinc finger factors that bind GATA sequences (GATA-1, GATA-2); GATA-1 partner, friend of GATA (FOG); erythroid Kruppel-like factor (EKLF) and p45NF-E2 (NF-E2). C) Receptors for hematopoietic growth factors: stem cell factor-receptor/c-kit; erythropoietin receptor (EPO-R) and insulin-like growth factor-1 receptor (IGF-1-R). D) Proteins related to erythrocyte structure and function. Modified by [39] and [32].

\begin{tabular}{|c|c|c|c|c|c|}
\hline $\begin{array}{l}\text { Trans-acting } \\
\text { factor }\end{array}$ & Binding motif & $\begin{array}{c}\text { Role in } \\
\text { hematopoiesis }\end{array}$ & Target genes & $\begin{array}{l}\text { Phenotype of gene } \\
\text { inactivation }\end{array}$ & Human pathology \\
\hline GATA-1 & $\begin{array}{c}(\mathrm{A} / \mathrm{T}) \mathrm{GATA} \\
(\mathrm{A} / \mathrm{G})\end{array}$ & $\begin{array}{c}\uparrow \text { Erythroid } \\
\text { differentiation }\end{array}$ & $\begin{array}{l}\text { Globin, erithroid, } \\
\text { specific membrane } \\
\text { proteins, GATA-1, } \\
\text { GATA-2 }\end{array}$ & $\begin{array}{l}\text { Anemia and } \\
\text { trombocytopenia }\end{array}$ & $\begin{array}{l}\text { X-linked thalassemia/ } \\
\text { trombocytopenia }\end{array}$ \\
\hline GATA-2 & $\begin{array}{c}\text { (A/T) GATA } \\
(\mathrm{A} / \mathrm{G})\end{array}$ & $\begin{array}{l}\uparrow \text { Proliferation } \\
\downarrow \text { Differentiation }\end{array}$ & GATA-1, GATA-2 & $\begin{array}{l}\text { No proliferation of } \\
\text { immature } \\
\text { progenitors }\end{array}$ & \\
\hline FOG-1 & None & GATA-1-cofactor & & $\begin{array}{l}\text { No erythroid } \\
\text { maturation }\end{array}$ & \\
\hline EKLF & CACC & $\begin{array}{l}\text { Promotes terminal } \\
\text { erythroid } \\
\text { differentiation }\end{array}$ & Globin & Anaemia & $\beta$-thalassemia \\
\hline SCL & CANNTG (E box) & $\begin{array}{l}\text { Specification of } \\
\text { hematopoiesis }\end{array}$ & & $\begin{array}{c}\text { Absence of prenatal } \\
\text { hematopoiesis }\end{array}$ & $\begin{array}{c}\text { Translocation in T- } \\
\text { ALL }\end{array}$ \\
\hline LM02 & Lim domain & & & $\begin{array}{c}\text { Absence of } \\
\text { hematopoiesis }\end{array}$ & $\begin{array}{c}\text { T-CELL acute } \\
\text { lymphocytic leukemia }\end{array}$ \\
\hline Myb & $\begin{array}{c}(\mathrm{T} / \mathrm{C}) \text { AAC }(\mathrm{G} / \mathrm{T}) \\
\mathrm{G}\end{array}$ & $\begin{array}{c}\downarrow \text { Definitive } \\
\text { erythropoiesis }\end{array}$ & & $\begin{array}{c}\text { Block in definitive } \\
\text { erythropoiesis }\end{array}$ & \\
\hline STAT 5 & GAS & $\begin{array}{c}\text { Antiapoptotic effect } \\
\text { at level of erythroid } \\
\text { precursors }\end{array}$ & BCL-XL & $\begin{array}{l}\text { Anemia due to } \\
\text { apoptosis of } \\
\text { erythroid progenitors }\end{array}$ & \\
\hline NFE 2 & TGAGTCA & $\begin{array}{c}\text { Promotes terminal } \\
\text { erythroid } \\
\text { differentiation in } \\
\text { vitro }\end{array}$ & $\begin{array}{l}\text { Enzyme of the } \\
\text { haem biosynthetic } \\
\text { pathway,globin }\end{array}$ & trombocytopenia & \\
\hline
\end{tabular}

Table 2. Major transcription factors/signaling molecules involved in the control of erythropoiesis. DNA-binding sites and known target genes of the indicated transcription factors together with the phenotype of their gene inactivation in mice and the human pathologies associated with gene mutations are shown.

\section{Iron metabolism and erythropoiesis}

Iron plays a pivotal role in cell survival and proliferation by regulating enzymatic activity and oxidation-reduction reactions. It is essential primarily for ensuring the transport of oxygen and 
for the catalysis of reactions involved in electron transfer, nitrogen fixation and DNA synthesis, but it is also toxic due to its capacity to react with oxygen and catalyze the production of reactive oxygen species. In solution, iron can exist in two states of oxidation, Fe (II) and Fe (III), and is very poorly soluble at physiological $\mathrm{pH}$, especially when it is in the oxidized form Fe (III). Living organisms have thus developed many proteins to carry iron in biological fluids and transport it through cellular membranes, and to store it in a non-toxic and easily mobilizable form [70-72]. Erythropoiesis and iron metabolism are processes closely linked to each other. The large majority of iron in our body is utilized by the erythropoietic system to generate functionally active hemoglobin molecules, which are harbored in the red blood cells. It is estimated that $1800 \mathrm{mg}$ of iron in our body is present in red blood cells, $300 \mathrm{mg}$ in the bone marrow and $600 \mathrm{mg}$ in the reticuloendothelial macrophages of the spleen [71], accounting for more than $60 \%$ of total body iron. Approximately $10 \%$ is present in muscle fibers (in myoglobin) and other tissues (in enzymes and cytochromes) and the remaining body iron is stored in the liver. The normal diet contains $15-20 \mathrm{mg}$ of iron, and the body absorbs $1-2 \mathrm{mg} / \mathrm{d}$ of dietary iron. This is balanced with losses via sloughed intestinal mucosal cells, menstruation and other blood losses. Therefore, internal turnover of iron is essential to meet the bone marrow requirements for erythropoiesis (20-30 mg/d) (Fig. 4) [73-75]. This massive utilization of iron by the erythropoietic system requires the presence of finely tuned regulatory systems that allow storage, mobilization and traffic of iron and at the same time prevent toxicity due to highly reactiveironions. Because there are no physiologically regulated means of iron excretion, dietary iron absorption is highly regulated primarily at the level of duodenal enterocytes. Other important regulatory sites are the liver and the spleen. Hepatocytes and Kuppfer cells can store large quantities of iron, while iron from senescent red blood cells is recycled from macrophages in the spleen. All three compartments are of pivotal importance for erythropoiesis since they control the bioavailability of iron to erythroid progenitors, and all of them respond to hepcidin, the master regulator of iron metabolism [76]. A summary of proteins involved in iron homeostasis, as well as their most frequently used acronyms, is given in Table 3 and Table 4 . Transferrin is the main plasma iron transporter that binds two molecules of ferric iron (Fe3+). At the systemiclevel, transferrin satuaration is the mainiron sensor and plays a role in controlling the levels of the iron-regulatory peptide hepcidin [77]. Transferrin is usually between 20 and $30 \%$ satured with iron. At the cellular level we known two common mechanisms that can be applied to most of the proteins involved in iron metabolism regulation. First, iron- regulatory proteins 1 (IRP1) and 2 (IRP2) bind to iron-response elements (IREs) in the untranslated regions (UTRs) of mRNA encoding protein involved in cellular iron uptake, storage, and export. IRP1 and IRP2 bind to IREs under conditions of low iron, and they dissociate from IREs in highiron states [77-78]. If the IRE is in 3'UTR, IRP binding stabilizes the mRNA, prevents degradation, and increases protein production. If the IRE is in the 5'UTR, mRNA translation is inihibited. There are over 35 mRNAs, including hypoxia-inducible factor $2 \alpha$, that have an IRE and are responsive to iron. The second general mechanism imparts tissue-specific sensitivity to iron balance by modulation of the proportion of iron-sensitive and iron-insensitive mRNAs. This means that one variant responds to iron levels and one does not. The ratio of IRE to non-IRE differs in different tissues, resulting in differences in responsiveness to iron and differences in loading [77]. In specialized cell types, alternatively spliced non-IRE-containing isoforms of ferroportin [34] and DMT1 [79] mRNAs bypass post-transcriptional regulation by IRPs. Under normal circumstances, dietary ferric iron is reduced by cytochrome B to ferrous iron (Fe 2+) at 
the apical brush border of duodenal enterocytes and transported into the cell by DMT1. DMT1 expression is highest at the duodenum and decreases towards the colon. Dietary heme iron is absorbed into the enterocyte via the heme carrier protein-1 Inside the enterocyte, heme is degraded by heme oxygenase and iron is released into the cytosol. The free iron is stored in the cells by ferritin or exported to the plasma by FPN1 [77,80-81]. Exported iron is loaded onto transferrin. Before the loading of transferrin, ferrous iron is oxidized to Fe 3+ by hephaestin. Cells can then take up transferrin-bound iron via transferrin receptor 1 (Tfr1, aka CD71). Erythroblasts, the major iron consuming cells in the organism, mainly take up transferrinbound iron via transferrin receptor 1 (TfR1). Iron release takes place in vesicles of low $\mathrm{pH}$. Ferric iron is reduced to ferrous iron by Steap3 and subsequently exported into the cytosol via DMT1, while transferrin and TfR1 recycle to the surface. The bulk of intracellular iron in erythroblasts is used for hemoglobin synthesis, where mitochondria are indispensable for heme production. Excess heme is either exported via FLVCR or catabolized via the HO-1 pathway $[39,82]$. As the intake of nutritional iron is not sufficient to cover the daily iron necessity of erythropoiesis, iron recycling is necessary. Macrophages exert a crucial role in iron recycling, phagocytosing senescent erythrocytes, and releasing accumulated iron back into the circulation in a regulated manner, thus enabling iron recycling [82]. Phagocytosed erythrocytes are broken up in lysosomes, and heme-bound iron is released via HO-1. When body iron levels are low, storage iron re-enters the circulation. Ferroportin again functions as the only known iron exporter, and another plasma copper-containing ferroxidase coeruloplasmina converts ferrous into ferric iron before its loading onto transferrin [82]. Similar to reticuloendothelial cells, hepatocytes are an important site of iron storage in the form of ferritin. Most important, hepatocytes serve a central role in iron homeostasis as the site of regulated production of the hormone hepcidin. Hepcidin functions as the "hypoferremia hormone" by down-regulating the ferroportin-mediated release of iron into the circulation [83]. The consequent iron retention in duodenal enterocytes decreases dietary iron absorption and the iron retention in reticuloendothelial macrophages decreases iron turnover. Hepatocellular hepcidin production is regulated by signals reflecting inflammation, iron status, erythropoietic activity, and oxygen tension [83]. Major pathways of iron traffic between cells and tissues are indicated in Fig. 4.

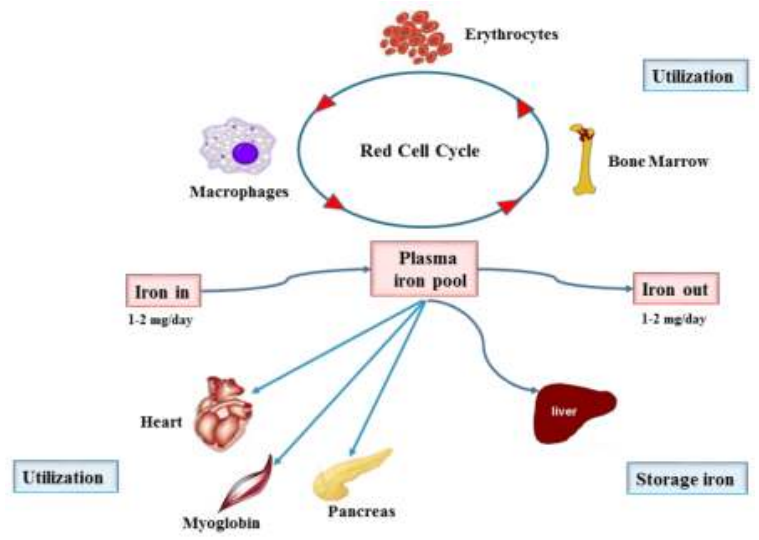

Figure 4. Major pathways of iron traffic between cells and tissues. 


\begin{tabular}{|c|c|c|c|}
\hline Protein name & Acronyms & Funcion in iron metabolism & Localization \\
\hline \multicolumn{4}{|l|}{ Iron aquisition } \\
\hline Transferrin & $\mathrm{Tf}$ & Plasma iron transfer & Plasma \\
\hline Transferrin receptor 1 & TfR1 & Internalization of holo-Tf & Ubiquitously expressed \\
\hline $\begin{array}{l}\text { Six transmembrane } \\
\text { epithelial antigen } \\
\text { of the prostate } 3\end{array}$ & STEAP3 & $\begin{array}{l}\text { Ferric reductase in the endosomes of } \\
\text { erythroid cells }\end{array}$ & erythroblast \\
\hline $\begin{array}{l}\text { Divalent metal } \\
\text { transporter } 1\end{array}$ & DMT1 & $\begin{array}{l}\text { Epithelial/endosomal transport } \\
\text { of ferrous iron }\end{array}$ & Enterocyte (apical membrane) \\
\hline Duodenal cytochrome b & Dcytb & $\begin{array}{l}\text { Apical membrane ferric } \\
\text { reductase of enterocytes }\end{array}$ & Enterocyte (apical membrane) \\
\hline Heme oxygenase 1 & $\mathrm{HO}-1$ & $\begin{array}{l}\text { Degradation of hemoglobin } \\
\text { for } \mathrm{Fe}^{2+} \text { release }\end{array}$ & Enterocyte \\
\hline Ferritin & $\mathrm{Ft}$ & Cellular iron storage and uptake & $\begin{array}{l}\text { Enterocyte, erythroblast, } \\
\text { macrophage, hepatocyte, } \\
\text { myocytes and cardiomyocytes }\end{array}$ \\
\hline \multicolumn{4}{|c|}{ Intracellular iron transport } \\
\hline Mitoferrin $1 / 2$ & MFRN 1/2 & $\begin{array}{l}\text { Import of ferrous iron to } \\
\text { mitochondria }\end{array}$ & Erythroblast (mitochondria) \\
\hline \multicolumn{4}{|l|}{ Iron efflux } \\
\hline Ferroportin & FPN1 & Export of ferrous iron & $\begin{array}{l}\text { Enterocyte (basolateral membrane) } \\
\text { Macrophages, hepatocytes, } \\
\text { Erythroid cells }\end{array}$ \\
\hline Hephaestin & HEPH & Membrane-bound ferroxidase & Enterocyte (basolateral) \\
\hline Ceruloplasmin & $\mathrm{CP}$ & Plasma ferroxidase & macrophage \\
\hline $\begin{array}{l}\text { Feline leukemia virus, } \\
\text { subgroup C, receptor }\end{array}$ & FLVCR & Heme export & Erythroblast \\
\hline
\end{tabular}

Table 3. Main proteins involved in iron homeostasis

\begin{tabular}{llll}
\hline $\begin{array}{l}\text { PROTEIN NAME } \\
\text { Systemic iron } \\
\text { metabolism }\end{array}$ & Acronyms & Function & Phenotype due to loss of function \\
\hline Hepcidin & HEPC & $\begin{array}{l}\text { Inhibition of ferroportin } \\
\text { mediated efflux }\end{array}$ & $\begin{array}{l}\text { Absent hepcidin expression. Iron } \\
\text { overload at the level of liver and } \\
\text { pancreas and at a lesser extent } \\
\text { of heart (HH type2A) }\end{array}$ \\
\hline
\end{tabular}




\begin{tabular}{|c|c|c|c|}
\hline $\begin{array}{l}\text { PROTEIN NAME } \\
\text { Systemic iron } \\
\text { metabolism }\end{array}$ & Acronyms & Function & Phenotype due to loss of function \\
\hline $\begin{array}{l}\text { Bone morphogenetic } \\
\text { protein } 6\end{array}$ & BMP6 & $\begin{array}{l}\text { Regulation of hepcidin } \\
\text { expression in response to } \\
\text { hepatic iron }\end{array}$ & $\begin{array}{l}\text { Iron overload with decreased } \\
\text { levels of hepcidin }\end{array}$ \\
\hline Hemojuvelin & HJV & $\begin{array}{l}\text { Enhancement of BMP signaling } \\
\text { to hepcidin }\end{array}$ & $\begin{array}{l}\text { Early onset severe iron overload } \\
\text { with suppressed hepcidin expression } \\
\text { (HH type2A) }\end{array}$ \\
\hline Transferrin & $\mathrm{Tf}$ & Plasma iron transfer & $\begin{array}{l}\text { Iron deficiency anemia with tissue iron } \\
\text { overload }\end{array}$ \\
\hline High Fe protein & HFE & $\begin{array}{l}\text { Regulation of hepcidin } \\
\text { expression by plasma iron }\end{array}$ & $\begin{array}{l}\text { Iron overload with decreased levels } \\
\text { of hepcidin (HH type } 1)\end{array}$ \\
\hline Transferrin receptor 2 & TfR2 & $\begin{array}{l}\text { Regulation of hepcidin } \\
\text { expression by plasma iron }\end{array}$ & $\begin{array}{l}\text { Iron overload with decreased levels of } \\
\text { hepcidin (HH type } 3)\end{array}$ \\
\hline SMAD 4 & SMAD4 & Signaling to hepcidin & Decreased hepcidin levels and iron overload \\
\hline Matriptase-2 & TMPRSS6 & Proteolytic cleavage of $\mathrm{Hjv}$ & $\begin{array}{l}\text { Macrocytic anemia with low iron } \\
\text { stores and increased hepcidin }\end{array}$ \\
\hline Neogenin & NEO & Regulation of $\mathrm{Hjv}$ & Hepatic iron overload \\
\hline \multicolumn{4}{|l|}{$\begin{array}{l}\text { Cellular iron } \\
\text { metabolism }\end{array}$} \\
\hline Iron regulatory protein & IRP 1 & $\begin{array}{l}\text { Post-transcriptional regulation } \\
\text { of IRE-containing mRNAs }\end{array}$ & Not known \\
\hline Iron regulatory protein & 2 IRP 2 & $\begin{array}{l}\text { Post-transcriptional regulation } \\
\text { of IRE-containing mRNAs }\end{array}$ & $\begin{array}{l}\text { Misregulation of iron metabolism. } \\
\text { Neurodegenerative disease due to } \\
\text { iron accumulation in neurons and } \\
\text { oligodendrocytes }\end{array}$ \\
\hline $\begin{array}{l}\text { F-box and leucine- } \\
\text { rich repeat protein } 5\end{array}$ & FBXL 5 & $\begin{array}{l}\text { Iron-dependent ubiquitination } \\
\text { and degradation of IRP } 2\end{array}$ & Embryonic lethality \\
\hline
\end{tabular}

Table 4. Main proteins involved in iron homeostasis regulation

\section{Hepcidin: The link between erythropoiesis and iron regulation}

In recent years, there has been important advancement in our understanding of iron metabolism, mainly as a result of the discovery of hepcidin, a key regulator of whole body iron homeostasis originally identified from urine as an antimicrobial peptide produced in the 
hepatocytes [84]. The aim of this chapter is beyond a complete picture of current knowledge on the hepcidin regulation, therefore I will focus only on those aspects that influence erythropoiesis directly or indirectly. Targeted deletion of the HAMP gene in mice or mutations in the human HAMP gene result in massive iron overload [85]. Conversely, high levels of hepcidin lead to decreased iron absorption and iron-restricted anemias. Therefore, hepcidin is a negative regulator of iron transport into plasma. Experimental data suggested that the hepcidin could be the regulator of iron absorption and recycling acting principally or solely by binding to ferroportin, the only known cellular iron exporter. The hepcidin-ferroportin interaction controls systemic iron homeostasis: hepcidin binds to ferroportin and induces its internalization and degradation. This mechanism regulates the distribution of iron in the body. When hepcidin levels are low, iron-exporting cells, including duodenal enterocytes, macrophages, and hepatocytes display abundant ferroportin and release iron into plasma. When hepcidin concentration increase, hepcidin binds to ferroportin, causing its phosphorylation, internalization, ubiquitylation, sorting through the multivesicular body pathway, and degradation in lysosomes, and iron is retained within cells in cytoplasmic ferritin [34,82,86-89]. Hepcidin is regulated at transcriptional level by different stimuli that can act as positive or negative regulators. The membrane isoform of hemojuvelin (HJV), transferrin receptor 2 (TfR2), IL-6, iron and the hemochromatosis protein HFE are all positive regulators of hepcidin transcription. On the contrary, hypoxia, anemia, iron deficiency, and erythroid expansion are all negative regulators of hepcidin expression. We know four major regulatory pathways that act through different signaling pathways to control the transcription of hepcidin, e.g. iron erythroid demand, hypoxia, iron store, and inflammation. Briefly, hepcidin transcription is activated by BMP-6 (Bone morphogenetic protein 6) via the SMAD pathway. Hemojuvelin (HJV) enhances the activity of the BMP receptor (BMP-R), while cleavage of HJV by TMPRSS6 suppresses this activity. Diferric Tf displaces the hemochromatosis protein (HFE) from the high-affinity transferrin receptor (TfR1) that associates with TfR2 enhancing signaling via BMP-R. Inflammatory cytokine IL-6 acts through its receptor (IL6-R) and the JAK2/STAT3 pathway to turn on hepcidin production. Growth differentiation factor 15 (GDF15), twisted gastrulation-1, erythroferrone (ERFE), hypoxia, and erythropoietin (Epo) reduce hepcidin transcription [89-93]. GDF15 is released by erythroid precursors and increased in hemoglobinopathies, e.g. thalassemia, congenital dyserythropoietic anemia type 1 , and refractory anemia with ring sideroblasts. GDF15 is decreased post transfusion, in parallel with EPO and decreased marrow activity, resulting in increase in hepcidin. Twisted gastrulation (TWSG1), soluble HJV, and erythroferrone (ERFE) are other factors that are rapidly produced with increased erythroid activity and result in reduced hepcidin production. ERFE belongs to the C1q-tumor necrosis factor-related family of proteins. In response to EPO, ERFE is rapidly produced by erythroid precursors in the bone marrow and the spleen via signal transducer and activator of transcription 5 (STAT5). The canonical Janus kinase 2 (Jak2)/Stat5 signaling pathway is a known mediator of EPO response and stress erythropoiesis. Further work is necessary to confirm whether ERFE is the long-sought erythroid regulator responsible for hepcidin suppression and iron overload in patients with hereditary iron- loading anemia [92, 94-97]. Regulation of hepcidin production is shown in Fig.5 


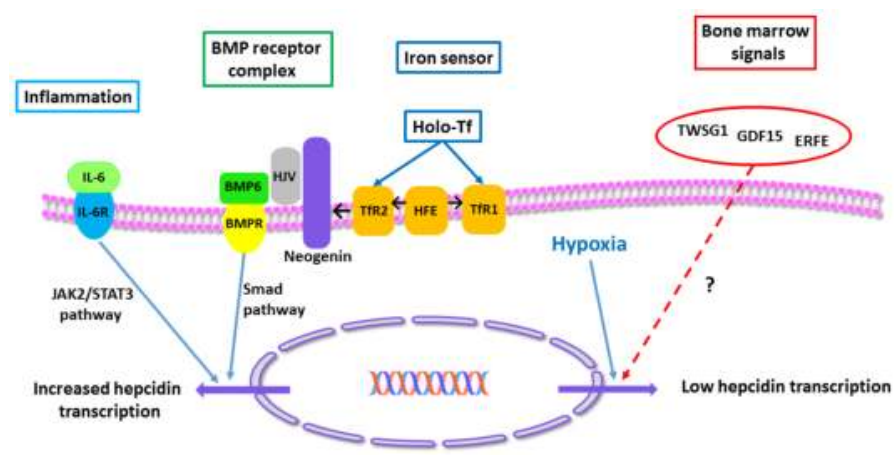

Figure 5. Iron-mediated regulation of hepcidin levels on hepatocytes.

\section{Ineffective erythropoiesis and iron overload in $\beta$-thalassemia}

In $\beta$-thalassemia the erythropoietic process is markedly altered and is referred to as ineffective erythropoiesis (IE). The lack or reduced synthesis of $\beta$-globin chains induces an excess of free $\alpha$-globin chains within erythroid cells. Aggregation, denaturation, and degradation of these chains leads to the formation of insoluble precipitates that cause oxidative membrane damage within the red blood cell and developing erythroblasts [98]. In $\beta$-thalassemia the process of IE is accompanied by a massive iron overload, due to an increased rate of iron absorption by the gastrointestinal (GI) tract and to frequent blood transfusions. Nevertheless, iron overload occurs also in patients who have not received transfusions such as patients suffering from thalassemia intermedia $[63,99]$. In patients who are iron- overloaded, the capacity of serum transferrin to bind iron may be exceeded, which means that a non-transferrin-bound fraction of iron may circulate in the plasma. This unbound iron, which is carried in the iron storage protein ferritin, can promote the generation of free hydroxyl radicals, which propagate oxygenrelated tissue damage. Additionally, insoluble iron complexes called hemosiderins may become deposited in body tissues causing toxicity and death. Cardiac failure is a major complication of iron overload. Iron deposition can cause myocarditis and cardiac fibrosis. There are a number of other possible complications of iron overload: excess iron deposition in the liver can lead to fibrosis/cirrhosis or cancer, and diabetes mellitus may occur as a result of beta-cell destruction secondary to iron overload in the pancreas. Excess iron overload in the pituitary may cause growth failure due to hypogonadism and infertility due to reduced gonadotropin levels [86,100-101]. If iron were a dominant regulator, patients with $\beta$-thalassemia should express very high levels of hepcidin in serum in order to decrease intestinal iron absorption. In contrast, the levels of hepcidin are very low in these patients, suggesting that the ineffective erythropoiesis alone is able to suppress the synthesis of hepcidin in spite of the presence of a severe iron overload [89,102-104]. Hepcidin deficiency develops as a result of a suppressive signal generated by the greatly expanded erythroid precursor population. This also leads to excessive iron absorption and the development of iron overload even in patients who are not transfused. Although the hepcidin suppression is partially relieved by erythrocyte 
transfusions, the transfusions themselves add large amounts of exogenous iron again leading to iron overload. The observation that serum from $\beta$-thalassemic patients inhibited hepcidin mRNA expression in the HepG2 cell line suggested the existence of a negative erythropoietic regulator of hepcidin expression [105]. The nature of this humoral factor is still uncharacterized, but may include one or more proteins during active erythropoiesis. One of this regulators could be the cytokine growth differentiation factor-15 (GDF15) because it was observed that serum from thalassemia patients suppressed hepcidin mRNA expression in primary human hepatocytes and depletion of GDF15 reversed the hepcidin expression. GDF15 is a divergent member of the transforming growth factor-beta superfamily that is secreted by erythroid precursors and other tissues. It has been identified as an oxygen-regulated transcript responding to hypoxia and as a molecule involved in hepcidin regulation. It was suggested that GDF15 overexpression arising from an expanded erythroid compartment contributed to iron overload in thalassemia syndromes by inhibiting hepcidin expression, possibly by antagonizing the BMP pathway [89,93]. GDF15 mRNA levels and secreted protein were up-regulated in response to iron depletion in a range of human cell lines and "in vivo" in humans and this upregulation was independent of HIF suggesting the existence of a novel iron and oxygensensing pathway [106]. Finally, the observation that GDF15 was induced by over-expression of wild type ferroportin connects the iron-mediated regulation of GDF15 concentration to patho-physiological levels of iron. Despite systemic iron overload, ineffective erythropoiesis and associated iron-fluxes in beta-thalassemia might generate an iron deficiency signal in a relevant molecular or cellular context and consequent stimulation of GDF15 expression in a particular erythroid compartment [106]. Experimental data provided the evidence that TWSG1 could be potentially involved in the regulation of hepcidin by erythropoiesis. In contrast to GDF15, the expression of human twisted gastrulation factor (TWSG1) occurs early during erythroblast maturation before hemoglobinization of the cells. TWSG1 is another highly expressed serum protein in thalassemia suppressing hepcidin transcription by interfering with BMP signaling either directly, by acting on BMP receptors, or indirectly by influencing circulating BMP2 and BMP4 levels. So it was proposed that TWSG1 might act with GDF15 to dysregulate iron homeostasis in $\beta$-thalassemia [107]. Results obtained by HuH7 hepatoma cells cocultered with primary human erythroblasts or erythroleukemic UT7 cells presented a 20- to 35-fold increase of hepcidin expression and identified OsM responsible for this increase of hepcidin levels. In contrast to GDF15 and TWSG1, it was showed that OsM could induce hepcidin transcription in human hepatoma cell lines mainly through the JAK/STAT pathways [108-109].

\section{New therapeutic approaches to limit iron absorption in $\beta$-thalassemia}

For its frequency and severity $\beta$-thalassemia represents a significant health problem in various areas of the world. Conventional treatment of thalassemia includes transfusion therapy, iron chelation therapy and, in rare cases, splenectomy. Regular blood transfusions in combination with aggressive iron chelation have been remarkably effective in delaying the onset of ironrelated organ failure and improving mortality but, in spite of this, many patients continue to be affected by cardiac disease and other clinical complications, e.g. develop endocrine failure and delayed pubertal maturation. To add that this rigorous life-long treatment regime is 
onerous and represents an enormous imposition on quality of life. Allogeneic hemopoietic stem cell transplantation is the only approach that may lead to a definitive cure but it is not available to most patients. The understanding of $\beta$-thalassemia pathophysiology has involved more than 50 years of biochemical and biological studies leading to the development of alternative therapies to cure or ameliorate the disease. New potential molecular targets for $\beta$ thalassemic therapy can be divided into three categories. To the first category belong the primary targets that include all of the molecular defects that lead to a decrease in $\beta$-globin synthesis. Hemopoietic stem cell transplantation (HSCT), gene therapy using viral vectors and antisense mRNA are an example of strategies targeting the primary causes of reduced $\beta$-globin expression. To the second category belong the secondary targets including modifiers of chain imbalance in $\beta$-thalassemia by increasing of $\gamma$-globin synthesis. Gene therapy approaches for the induction of $\mathrm{HbF}$ synthesis include transduction of lentiviral vectors incorporating $\gamma$ globin/ $\beta$-LCR, or attemps to promote endogenous gamma-globin expression using artificial transcription factors. Pharmacological approaches for the induction of gamma-synthesis include the treatment with erythropoietin (EPO) preparations, or short chain fatty acid derivatives (SCFADs) or chemotherapeutic agents as hydroxycarbamide (HU) and 5-azacytidine. To the third category belong the tertiary targets that are those directed at treating the complications of $\beta$-thalassemia such as iron overloading and oxidative cellular damage [23$25,89]$. In recent years increasing experimental evidences indicated that there was a potential for therapeutic intervention in $\beta$-thalassemia by means of manipulating iron metabolism [110 113]. In mice that completely lack Stat5 activity, it was observed that cell surface levels of TfR1 on erythroid cells were decreased more than 2-fold suggesting a link between EpoR/Jak/Stat signaling and iron metabolism [114]. Another study suggested a direct involvement of Epo in hepcidin regulation through the transcriptional factor C/EBP alpha [115]. It was also observed a link between Jak2 and FPN1: Jak2 phosphorylates FPN1 following its binding to hepcidin triggering its internalization and degradation [116]. Therefore, Jack2 might represent one of the major links at the interface between erythropoiesis and iron metabolism suggesting that use of Jak2 inhibitors, antioxidant, and analog of the hepcidin might reduce ineffective erythropoiesis and abnormal iron absorption. Several JAK2 inhibitors have already been developed, showing significant and beneficial results in myelofibrosis and JAK2-related polycythemia vera [117]. However, trials with JAK2 inhibitors in myeloproliferative disorders have also shown several side effects, among them thrombocytopenia and anemia. On the contrary, in preclinical thalassemic models, splenomegaly was reversed in less than two weeks and no side effects were observed [117]. Administration of synthetic hepcidin or of agents that increase its expression, may be beneficial in controlling absorption of this metal. Hepcidin agonists or stimulators of hepcidin production are being developed for the treatment or prevention of iron overload in hepcidin deficiency states, including hereditary hemochromatosis and $\beta$-thalassemia. It was observed that transgenic hepcidin therapy improved iron overload as well as erythropoiesis in the mouse model of $\beta$-thalassemia [118]. The rationale for the use of hepcidin agonists is justified by two principal observations: first, the phlebotomy is an inexpensive and effective treatment for iron overload that is acceptable to must but not all patients affected by hereditary hemochromatosis; second, the iron-loading anemias cannot be treated in this manner and require iron chelation therapy, which is not well tolerated by many patients. Hepcidin agonists are agents that replace hepcidin activity or stimulate its 
endogenous production and, in both of hereditary hemochromatosis and iron-loading anemias, could prevent iron accumulation by redistributing iron from parenchymal tissues to macrophages where iron is less toxic. Results obtained treating a mouse model of $\beta$-thalassemia with hepcidin agonists suggested that the use of these agents could not only prevent iron overload but could also improve erythropoiesis, perhaps by decreasing excessive alpha-globin synthesis or diminishing oxidative stress in erythropoietic precursors [119-120]. Minihepcidins are short peptide mimetics (9AA long) that are sufficient to induce FPN1 degradation in reporter cells. The extracellular loop of ferroportin surrounding the thiol cysteine C326 appears to be essential for hepcidin binding, as indicated by the lack of hepcidin binding to otherwise fully functional ferroportin containing the isosteric mutation C3265 [119]. Analysis of the interface between hepcidin and ferroportin showed that the segment composed of a $9 \mathrm{~N}$ terminal amino acid segment of hepcidin is sufficient for binding and internalization of ferroportin [121]. These small modified mini-hepcidin peptides show bioactivity in vivo, as determined by their ability to induce hypoferremia in mice and to prevent iron accumulation in hepcidin-deficient mice [119]. Potential drug target also is the transmembrane protease serine 6 (TMPRSS6) or Matriptase-2, a transmembrane serine protease that attenuates hepcidin expression. The fundamental role of TMPRSS6 on hepcidin expression is underscored by the observation that patients and mice with mutations in this gene are affected by iron-refractory iron deficiency anemia (IRIDA) [117]. In Hbbth3/+ mice, use of both antisens oligonucleotide (Tmprss6-ASO9) and RNA interference (Tmprss6-siRNA) can reduce the synthesis of transmembrane serine protease TMPRSS6 by degrading the corresponding mRNA. This led to increased hepcidin expression, decreased Tf-sat, and reduction of hemichrome formation and apoptosis in erythroid cells suggesting that these Tmprss6 inhibitors could be beneficial in individuals with $\beta$-thalassemia [117]. Hepcidin levels can be also altered by targeting a bone morphogenetic protein-dependent (BMP-dependent) pathway known to be central to the regulation of hepcidin expression. This pathway involves a multitude of extracellular factors such as GDF15 and TWSG1. These factors are both BMP antagonists produced by erythroblasts that inhibit hepcidin expression in vitro, suggesting their role as putative components of the erythroid regulator [122]. A major goal of hemoglobinopathy research is to develop treatments that correct the underlying molecular defects responsible for $\beta$-thalassemia. One approach to achieving this goal is the reactivation of $\gamma$-globin synthesis by farmacologic induction. Many of the events controlling the activity of the $\beta$-globin locus are known, but the details of those regulating normal human hemoglobin switching and reactivation of $\mathrm{HbF}$ in adult hematopoietic cells remain to be elucidated. Agents that increase human $\mathrm{HbF}$ in patients may work at one or more levels: for example, hydroxyurea and 5-azacytidine kill dividing cells preferentially and may increase $\gamma$-globin expression indirectly through this effect; butyrate may work both by increasing $\gamma$-globin translation on ribosomes and by inhibition of histone deacetylase (HDAC) $[39,112,123]$. It was showed that Stem Cell Factor (SCF) induced an "in vitro" expansion of effective erythropoiesis and a reactivation of $\gamma$-globin synthesis up to fetal levels, paving the way to its potential use in the therapeutic treatment of this disease [124]. Recently it was reported the ability of thalidomide to increase $\gamma$-globin gene expression and the proportion of HbF-containing cells in a human "in vitro" erythroid differentiation system. This study has also showed that thalidomide induced production of ROS causing p38 MAPF phosphorylation and globally increased histone H4 acetylation [125]. However, the mecha- 
nisms of action of these agents are not yet defined and their role in $\beta$-thalassemia therapy is still being explored in light of its acceptable toxicity profiles adding to their promise as therapeutic agents. Key genes controlling fetal/adult globin switching have been identified (e.g. BCL11 and CMYB) and may ultimately serve as direct targets for small molecules that would increase $\mathrm{HbF}$ levels in $\beta$-thalassemic patients [126-127]. Finally, the fact that most $\mathrm{HbF}-$ inducing agents are cytotoxic and many activate the p38MAPK cell stress signaling pathway suggested the importance of what has been termed the "integrated stress response" pathway in erythroid cells to understanding $\mathrm{HbF}$ induction. A variety of stress stimuli activate this pathway in erythroid cells: viral infection, ROS, heat shock, NO, ultraviolet irradiation, endoplasmic reticulum stress, inadequate nutrients, proteasome inhibition and limiting amounts of heme [112].

\section{Conclusion}

The discovery of hepcidin and its role in iron homeostasis has revolutionized our understanding of the pathogenesis of iron overload and iron-restricted anemias and has stimulated the development of new diagnostic and therapeutic methods for these disorders. Several physiological stimuli regulate the production of the iron-regulatory hormone hepcidin: iron loading, inflammation, and erythropoiesis. These stimuli modulate iron availability for erythropoiesis and other physiological processes and regulate the level of body iron stores by altering hepcidin levels. However, important scientific questions still remain to be answered. Further work is required to understand the mechanisms of hepcidin regulation by iron and erythroid activity; to elucidate the structure, the transport function and the complex regulation of the hepcidin receptor ferroportin; to define the hepcidin role in iron homeostasis. In the coming years, these efforts are likely to yield new therapeutical approaches for the treatment of anemia and iron overload disorders.

\section{Acknowledgements}

I thank Andrea Occhetti for his contribution to the figures and tables.

\section{Author details}

Nadia Maria Sposi*

Address all correspondence to: nadia.sposi@iss.it

Department of Hematology, Oncology and Molecular Medicine, Istituto Superiore di Sanità, Rome, Italy 


\section{References}

[1] Galanello R, Origa R. Beta-thalassemia. Orphanet J Rare Dis. 2010;21:5-11. DOI: 10.1186/1750-1172-5-11.

[2] Flint J, Harding RM, Boyce AJ, Clegg JB. The population genetics of the hemoglobinopathies. Baillieres Clin Haematol. 1998;11(1):1-51.

[3] Weatherall DJ, Clegg JB, Higgs DR and Wood WG. The hemoglobinopathies. In: Scriver CR, Beaudet AL, Sly WS, Valle D, Vogelstein B, editors. The Metabolic and Molecular Bases of Inherited Disease (OMMBID); Chapter 101. New York, NY: McGraw-Hill. 2002.

[4] Cao A, Galanello R. Beta-thalassemia Genet Med. 2010;12(2):61-76.

[5] Wood B, Higgs D. Molecular basis of thalassemia syndromes. ESH Handbook on Disorders of Erythropoiesis, Erythrocytes and Iron Metabolism. 2009; chapter 10:250 263.

[6] Galanello R, Cao A. Relationship between genotype and phenotype. Thalassemia intermedia. Ann NY Acad Sci. 1998;850:325-333.

[7] Weatherall D. The molecular basis for phenotypic variability of the common thalassemias. Mol Med Today. 1995;1:15-20.

[8] Camaschella C, Mazza U, Roetto A, Gottardi E, Parziale A, Travi M, Fattore S, Bacchiega D, Fiorelli G, Cappellini MD. Genetic interactions in thalassemia intermedia: Analysis of beta-mutations, alpha-genotype, gamma-promoters, and beta-LCR hypersensitive sites 2 and 4 in Italian patients. Am J Hematol. 1995;48(2):82-87.

[9] Cappellini MD, Musallam KM, Cesaretti C, Taher A. Thalassemia intermedia. ESH Handbook on Disorders of Herythropoiesis, Erythrocytes and Iron Metabolism. 2009; chapter 12:286-309.

[10] Li Q, Peterson KR, Fang X, Stamatoyannopoulos G. Locus control regions. Blood. 2002;100:3077-3086.

[11] Palstra RJ, de Laat W, Grosveld F. $\beta$-globin regulation and long-rage interactions. Adv Genet. 2008;61:107-142.

[12] Higgs DR, Engel JD, Stamatoyannopoulos G.Thalassemia. Lancet. 2012;379:373-383.

[13] Schrier SL. Pathophysiology of thalassemia. Curr Opin Hematol. 2002;9(2):123-126.

[14] Nienhuis AW, Nathan DG. Pathophysiology and clinical manifestations of the $\beta$-thalassemias. Cold Spring Harb Perspect Med. 2012 Dec. 1;2(12):a011726.

[15] Boyer SH, Belding TK, Margolet L, Noyes AN. Fetal hemoglobin restriction to a few erythrocytes (F cells) in normal human adults. Science. 1975;188:361-363. 
[16] Uda M, Galanello R, Sanna S, Lettre G, Sankaran VG, Chen W, Usala G, Busonero F, Maschio A, Albai G, Piras MG, Sestu N, Lai S, Dei M, Mulas A, Crisponi L, Naitza S, Asunis I, Deiana M, Nagaraja R, Perseu L, Satta S, Cipollina MD, Sollaino C, Moi P, Hirschhorn JN, Orkin SH, Abecasis GR, Schlessinger D, Cao A. Genome-wide association study shows BCL11A associated with persistent fetal hemoglobin and amelioration of the phenotype of beta-thalassemia. Proc Natl Acad Sci U S A. 2008;105(5): $1620-1625$.

[17] Aessopos A, Farmakis D, Deftereos S, Tsironi M, Tassiopoulos S, Moyssakis I, Karagiorga $\mathrm{M}$. Thalassemia heart disease: A comparative evaluation of thalassemia major and thalassemia intermedia. Chest. 2005;127(5):1523-1530.

[18] Telfer P, Coen PG, Christou S, Hadjigavriel M, Kolnakou A, Pangalou E, Pavlides N, Psiloines M, Simamonian K, Skordos G, Sitarou M, Angastiniotis M. Survival of medically treated thalassemia patients in Cyprus. Trends and risk factors over the period 1980-2004. Haematologica. 2006;91(9):1187-1192.

[19] Modell B, Khan M, Darlison M, Westwood MA, Ingram D, Pennell DJ. Improved survival of thalassaemia major in the UK and relation to $\mathrm{T} 2 *$ cardiovascular magnetic resonance. J Cardiovasc Magn Reson. 2008;10:42.

[20] Stamatoyannopoulos G, Grosveld F. Hemoglobin switching. In: Stamatoyannopoulos G, Majerus PW, Pelmutter RM, Vermus H, editors. The molecular basis of blood diseases. 3rd edn. Philadelphia: WB Saunders Company. 2001;136:82.

[21] Weatherall DJ, Clegg JB. The thalassemia syndrome, 4th edn. Oxford: Blackwell Science, 2001.

[22] Voon HP, Vadolas J. Controlling $\alpha$-globin: A review of $\alpha$-globin expression and its impact on $\beta$-thalassemia. Haematologica. 2008;93:1868-1876.

[23] Thein SL. Genetic modifiers of the $\beta$-haemoglobinopathies. Br J Haematol. 2008;141:357-366.

[24] Pace BS, Zein S. Understanding mechanisms of $\gamma$-globin gene regulation to develop strategies for pharmacological fetal hemoglobin induction. Dev Dyn. 2006;235:17271737.

[25] Perrine SP. Fetal globin stimulant therapies in the $\beta$-hemoglobinopathies: Principle and current potential. Pediatr Ann. 2008;37:339-346.

[26] Trompeter S, Roberts I. Hemoglobin F modulation in childhood sickle cell disease. Br J Hematol. 2009;144:308-316.

[27] Orkin SH, Zon LI. Hematopoiesis: an evolving paradigm for stem cell biology. Cell. 2008;132(4):631-644.

[28] Palis J. Ontogeny of erythropoiesis. Current Opinion in Hematology. 2008;15(3):155161. 
[29] Tsiftsoglou AS, Vizirianakis IS, Strouboulis J. Erythropoiesis: Model systems, molecular regulators, and developmental programs. IUBMB Life. 2009;61(8):800-830.

[30] Weissman IL. Stem cells: Units of development, units of regeneration, and units in evolution. Cell. 2000;100(1):157-168.

[31] Ingley E, Tilbrook PA, Klinken SP. New insights into the regulation of erythroid cells. IUMBMB Life. 2004;56(4):177-184.

[32] Koury MJ, Sawyer ST, Brandt SJ. New insights into erythropoiesis. Current Opinion in Hematology. 2002;9(2):93-100.

[33] Stamatoyannopoulos G. Control of globin gene expression during development and erythroid differentiation. Experimental Hematology. 2005;33(3):259-271.

[34] Cianetti L, Gabbianelli M, Sposi NM. Ferroportin and erythroid cells: An update. Advance in Hematology. 2010; vol. 2010, Article ID 404173, 12 pages.

[35] Golde DW. The stem cell. Scientific American. 1991;265(6):86-93.

[36] Metcalf D. The molecular control of cell division, differentiation committment and maturation in hemopoietic cells. Nature. 1989;339(6219):27-30.

[37] Orkin SH. Development of the hematopoietic system. Current Opinion in Genetics and Development. 1996;6(5):597-602.

[38] Emerson SG, Thomas S, Ferrara JL, Greenstein JL. Developmental regulation of erythropoiesis by hematopoietic growth factors: Analysis on populations of BFU-E from bone marrow, peripheral blood, and fetal liver. Blood. 1989;74(1):49-55.

[39] Sposi NM. Relationship between iron and erythropoiesis. In: Sarika Arora (Ed) Iron Metabolism. ISBN: 978-953-51-0605-0. InTech. 2011;61-86.

[40] Domen J, Weissman IL. Self-renewal, differentiation or death: Regulation and manipulation of hematopoietic stem cell fate. Molecular Medicine Today. 1999;5(5):201-208.

[41] Ogawa M. Differentiation and proliferation of hematopoietic stem cells. Blood. 1993;81(11):2844-2853.

[42] Grover CB Jr. Hematopoiesis. The molecular basic of blood. 1994, Sander ed.

[43] Bernstein ID, Andrews RG, Zsebo KM. Recombinant human stem cell factor enhances the formation of colonies by CD34+ and CD34 + lin- cells, and the generation of colony-forming cell progeny from CD34 + lin- cells cultured with interleukin-3, granulocyte colony-stimulating factor, or granulocyte-macrofage colony-stimulating factor. Blood 1991;77(11):2316-2321.

[44] Gabbianelli M, Pelosi E, Montesoro E, Valtieri M, Luchetti L, Samoggia P, Vitelli L, Barbieri T, Testa U, Peschle C. Multi-level effects of flt3 ligand on human hematopoiesis: Expansion of putative stem cells and proliferation of granulomonocytic progenitors/monocytic precursors. Blood 1995;86(5):1661-1670. 
[45] Lyman SD, James L, Johnson L, Brasel K, De Vries P, Escobar SS, Downwy H, Splett RR, Beckmann MP, McKenna HJ. Cloning of the human homolog of the murine flt3 ligand: A growth factor for early hematopoietic progenitor cells. Blood. 1994;83(10): 2795-2801.

[46] Berardi AC, Wang A, Abraham J, Scadden DT. Basic fibroblast growth factor mediates its effects on committed myeloid progenitors by direct action and has no effect on hematopoietic stem cells. Blood. 1995;86(6):2123-2129.

[47] Gabbianelli M, Sargiacomo M, Pelosi E, Testa U, Isacchi G, Peschle C. Pure human hematopoietic progenitors: Permissive action of basic fibroblast growth factor. Science. 1990;249(4976):1561-1564.

[48] Leary AG, Ikebuchi K, Hirai Y, Wong GG, Yang YC, Clark SC, ad Ogawa M. Sinergism between interlukin-6 and interleukin-3 in supporting proliferation of human hematopoietic stem cells: comparison with interleukin-1 alpha. Blood. 1988;71(6): 1759-1763.

[49] Metcalf D. Hematopoietic regulators: Redundancy or subtlety? Blood. 1993;82(12): 3515-3523.

[50] Fried W. Erythropoietin. Annual Review of Nutrition. 1995;15:353-377.

[51] Krantz SB. Erythropoietin. Blood. 1991;77(3):419-434.

[52] Demetri GD, Griffin JD. Granulocyte colony-stimulating factor and its receptor. Blood. 1991; 78(11):2791-2808.

[53] Sherr CJ. Colony-stimulatin factor-1 receptor. Blood. 1990;75(1):1-12.

[54] Kaushanky K, Lok S, Holly RD, Broudy VC, Lin N, Bailey MC, Forstrom JW, Buddle MM, Oort PJ, Hagen FS, Roth GJ, Papayannopoulou T, Foster DC. Promotion of megakaryocyte progenitor expansion and differentiation by the c-Mpl ligand thrombopoietin. Nature. 1994;369(6481):568-571.

[55] Testa U, Pelosi E, Peschle C. The transferrin receptor. Critical Reviews in Oncogenesis. 1993;4(3):241-276.

[56] Testa U. Recent developments in the understanding of iron metobolism. The Hematology Journal. 2002;3(2)63-89.

[57] Loken MR, Shah VO, Dattilio KL, Civin CI. Flow cytometric analysis of human bone marrow: I. Normal erythroid development. Blood. 1987;69(1):255-263.

[58] Okumura N, Tsuji K, Nakahata T. Changes in cell surface antigen expressions during proliferation and differentiation of human erythroid progenitors. Blood. 1992;80(3): 642-650.

[59] Ponka P. Tissue-specific regulation of iron metabolism and heme synthesis: Distinct control mechanisms in erythorid cells. Blood. 1997;89(1):1-25. 
[60] Andrews NC. Iron homeostasis: Insights from genetics and animal models. Nature Reviews. Genetics. 2000;1(3):208-217.

[61] Gregory T, Yu C, Ma A, Orkin H, Blobel GA, Weiss Mj. GATA-1 and erythropoietin cooperate to promote erythroid cell survival by regulating bcl-x(L) expression. Blood. 1999;94(1): 87-96.

[62] Kim SI, Bresnik EH. Transcriptional control of erythropoiesis: Emerging mechanisms and principles. Oncogene. 2007;26:6777-6794.

[63] Ribeil JA, Arlet JB, Dussiot M, Moura IC, Courtois G, Hermine O. Ineffective erythropoiesis in $\beta$-thalassemia. Hindawi Publishing Corporation. The Scientific World Journal. 2013;2013, Article ID 394295, 11 pages.

[64] Fang J, Menon M, Kapelle W, Bogacheva O, Bogachev O, Houde E, Browne S, Sathyanarayana P, Wojchowski DM. Epo modulation of cell-cycle regulatory genes, and cell division, in primary bone marrow erythroblasts. Blood. 2007;110:2361-2370.

[65] Socolovsky M, Murrel M, Liu Y, Pop R, Porpiglia E, Levchenko A. Negative autoregolation by FAS mediates robust fetal erythropoiesis. PLoS Biology. 2007;5(10):article e252.

[66] Menon MP, Karuz V, Bogachava O, Bogachev O, Cuetara B, Wojchowski DM. Signals for stress erythropoiesis are integrated via an erythropoietin receptor-phosphotyrosine 343-Stat5 axis. Journal of Clinical Investigation. 2006;116:683-694.

[67] Hengartner MO. The biochemistry of apoptosis. Nature. 2000;407:770-776.

[68] Yi CH, Yuan J. The Jekyll and hyde functions of caspases. Developmental Cell. 2009;16(1):21-34.

[69] Visvader JE, Mao X, Fujiwara Y, Hahm K, Orkin SH. The LIM-domain binding protein Ldb1 and its partner LMO2 act as negative regulators of erythroid differentiation. Proc Natl Acad Sci USA. 1997;94(25):13,707-13,712.

[70] Beaumont C, Vaulont S. Iron homeostasis. ESH Handbook Disorders of iron homeostasis, erythrocytes, erythropoiesis. 2006;Cap.18:393-406.

[71] Hentze MW, Muckenthaler MV, Andrews NC. Balancing acts: Molecular control of mammalian iron metabolism. Cell. 2004;117:285-297.

[72] Yun S, Vincelette ND. Update on iron metabolism and molecular perspective of common genetic and acquired disorder, hemochromatosis. Crit Rev. Oncol Hematol. 2015 Feb. 18. pii: S1040-8428(15)00,030-X. doi: 10.1016/j.critrevonc.2015.02.006.

[73] Munoz M, Villar I, Garcia-Erce JA. An update on iron physiology. World J Gastroenterol. 2009;15(37):4617-4626.

[74] Andrews NC. Disorders of iron metabolism. N Engl J Med. 1999;341:1986-1995. 
[75] Siah CW, Ombiga J, Adams LA, Trinder D, Olynyc JK. Normal iron metabolism and the pathophysiology of iron overload disorders. Clin Biochem Rev. 2006;27:5-16.

[76] Fleming RE, Bacon BR. Orchestration of iron homeostasis. N Engl J Med. 2005;352:1741-1744.

[77] Coates TD. Physiology and pathophysiology of iron in hemoglobin-associated diseases. Free Radical Biology and medicine 2014;72:23-40.

[78] Anderson CP, Shen M, Eisenstein RS, Leibold EA. Mammalian iron metabolism and its control by iron regulatory proteins. Biochim. Biophys. Acta. 2012;1823:1468-1483.

[79] Hubert N, Hentze MW. Previously uncharacterized isoforms of divalent metal transporter (DMT)-1: Implications for regulation and cellular function. Proc Natl Acad Sci USA. 2002;99:12,345-12,350.

[80] Anderson GJ, Frazer DM, Mc Laren GD. Iron absorption and metabolism. Curr Opin Gastroenterol. 2009;25:129-135.

[81] Donovan A, Roy CN, Andrews NC. The ins and outs of iron homeostasis. Physiology (Bethesda). 2006;21:115-123.

[82] Evstatiev R, Gasche C. Iron sensing and signaling. Gut. 2012;61:933-952.

[83] Fleming RE, Ponka P. Iron overload in human disease. $N$ Engl J Med. 2012;366:348:359.

[84] Park CH, Valore EV, Waring AJ, Ganz T. Hepcidin, a urinary antimicrobial peptide synthesized in the liver. Journal of Biological Chemistry. 2001;276:7806-7810.

[85] Nicolas G, Bennoun M, Devaux I, Beaumont C, Grandchamp B, Kahn A, Vaulont S. Lack of hepcidin gene expression and severe tissue iron overload in upstream stimulatory factor 2 (USF2) knockout mice. Proc Natl Acad Sci USA. 2001;98:8780-8785.

[86] Fleming RE, Sly WS. Hepcidin: A putative iron regulatory hormone relevant to hereditary hemochromatosis and the anemia of chronic disease. Proc Natl Acad Sci USA. 2001;98:8160-8162.

[87] Nicolas G, Chauvet C, Viatte L, Danan JL, Bigard X, Devaux I, Beaumont C, Kahn A, Vaulont $S$. The gene encoding the iron regulatory peptide hepcidin is regulated by anemia, hypoxia and inflammation. Journal of Clinical Investigation. 2002;110:10371044.

[88] Ganz T. Cellular iron: Ferroportin is the only way out. Cell Metabolism. 2005;1:155157.

[89] Piperno A, Mariani R, Trombini P, Girelli D. Hepcidin modulation in human diseases: From research to clinic. World Journal of Gastroenterology. 2009;15:538-551.

[90] Andrews NC. Forging a field: The golden age of iron biology. Blood. 2008;112:219230. 
[91] Rivella S. The role of ineffective erythropoiesis in non-transfusion dependent thalassemia. Blood Rev. 2012;26(Suppl.1):512-515.

[92] Pasricha SR, Frazer DM, Bowden DK, Anderson GJ. Transfusion suppresses erythropoiesis and increases hepcidin in adult patients with beta-thalassemia major: A longitudinal study. Blood. 2013;122:124-133.

[93] Tanno T, Bhanu NV, Oneal PA, Goh SH, Staker P, Lee YT, Moroney JW, Reed CH, Luban NL, Wang RH, Eling TE, Childs R, Ganz T, Leitman SF, Funcharoen S, Miller JL. High levels of GDF15 in thalassemia suppress expression of the iron regulatory protein hepcidin. Nat Med. 2007;13:1096-1101.

[94] Silvestri L, Pagani A, Camaschella C. Furin-mediated release of soluble hemojuvelin: A new link between hypoxia and iron homeostasis. Blood. 2008;111:924-931.

[95] Kautz L, Jung G, Nemeth E, Ganz T. The erythroid factor erythroferrone and its role in iron homeostasis. Blood. 2013;122 (21).

[96] Kautz L, Jung G, Valore EV, Rivella S, Nemeth E, Ganz T. Identification of erythroferrone as an erythroid regulator of iron metabolism. Nature Genet. 2014;46:678-684.

[97] Kautz L, Nemeth E. Molecular liaisons between erythropoiesis and iron metabolism. Blood. 2014;124:479-482.

[98] Melchiori L, Gardenghi S, Rivella S. $\beta$-thalassemia: HiJAKing ineffective erythropoiesis and iron overload. Adv Haematol. 2010;2010:938,640.

[99] Pippard MS, Callender ST, Warner GT, Weatherall DJ. Iron absorption and loading in $\beta$-thalassemia intermedia. The Lancet. 1979;8147:819-821.

[100] Gardenghi S, Marongiu MF, Ramos P, Guy E, Breda L, Chadburn A, Liu Y, Amariglio N, Rechavi G, Rachmilewitz EA, Brener W, Cabantchik ZI, Wrighting DM, Andrews NC, de Sousa M, Giardina PJ, Grady RW, Rivella S. Ineffective erythropoiesis in beta-thalassemia is characterized by increased iron absorption mediated by downregulation of hepcidin and up-regulation of ferroportin. Blood. 2007;109:5027-5035.

[101] Rivella S. Ineffective erythropoiesis and thalassemias. Current Opinion in Hematology. 2009;16:187:194.

[102] Ganz T. Hepcidin, a key regulator of iron metabolism and mediator of anemia of inflammation. Blood. 2003;102:783-788.

[103] Papanikolaou G, Tzilianos JI, Christakis JI, Bogdanos D, Tsimirika K, MacFarlane J, Goldberg YP, Sakellaropoulos N, Ganz T, Nemeth E. Hepcidin in iron overload disorders. Blood. 2005;105:4103-4105.

[104] Kattamis A, Papassotiriou I, Palaiologou D, Apostolakou F, Galani A, Ladis V, Sakellaropoulos N, Papanikolaou G. The effects of erythropoietic activity and iron burden on hepcidin expression in patients with thalassemia major. Haematologica. 2006;91:809-812. 
[105] Weizer-Stern O, Adamsky K, Amariglio N, Levin C, Koren A, Breuer W, Rachmilewitz E, Breda L, Rivella S, Cabantchik ZI, Rechavi G. Downregulation of hepcidin and haemojuvelin expression in the hepatocyte cell-line HepG2 induced by thalassemic sera. British Journal of Hematology. 2006;135:129-138.

[106] Lakhal S, Talbot NP, Crosby A, Stoepker C, Townsend AR, Robbins PA, Pugh CW, Ratcliffe PJ, Mole DR. Regulation of growth differentiation factor 15 expression by intracellular iron. Blood. 2009;113:1555-1563.

[107] Tanno T, Porayette P, Sripichai O, Noh SJ, Byrnes C, Bhupatiraju A, Lee YT, Goodnough JB, Harandi O, Ganz T, Paulson RF, Miller JL. Identification of TWSG1 as a second novel erythroid regulator of hepcidin expression in murin and human cells. Blood. 2009;114:181-186.

[108] Chung B, Verdier F, Matak P, Deschemin JC, Mayeux P, Vaulont S. Oncostatin M is a potent inducer of hepcidin, the iron regulatory hormone. The FASEB Journal. 2010;24:2093-2103.

[109] Kanda J, Uchiyama T, Tomosugi N, Higuchi M, Uchiyama T, Kawabata H. Oncostatin $\mathrm{M}$ and leukemia inhibitory factor increase hepcidin expression in hepatoma cell lines. International Journal of Hematology. 2009;90:545-552.

[110] Nemeth E. Iron regulation and erythropoiesis. Curr Opin Hematol. 2008;15:169-175.

[111] Tsiftsoglou AS, Tsamadou AI, Papadopoulou LC. Heme as key regulator of major mammalian cellular functions: molecular, cellular and pharmacological aspects. Pharmacology and Therapeutics. 2006;11:327-345.

[112] Mabaera R, West RJ, Conine SJ, Macari ER, Boyd CD, Engman CA, Lowrey CH. A cell stress signaling model of fetal hemoglobin induction: What doesn't kill red blood cells may make them stronger. Experimental Hematology. 2008;36:1057-1072.

[113] Rund D, Rachmilewitz E. Beta-thalassemia. New England Journal of Medicine. 2005;353:1135-1146.

[114] Kerenyi MA, Grebien F, Gehart H, Schifrer M, Artaker M, Kovacic B, Beug H, Moriggi R, Mullner EW. Stat5 regulates cellular iron uptake of erythroid cells via IRP-2 and TfR1. Blood. 2008;112:3878-3888.

[115] Pinto JP, Ribeiro S, Pontes H, Thowfeequ S, Tosh D, Carvalho F, Porto G. Erythropoietin mediates hepcidin expression in hepatocytes through EPOR signaling and regulation of C/EBP (alpha). Blood. 2008;111:5727-5733.

[116] De Domenico I, Lo E, Ward DM, Kaplan J. Hepcidin-induced internalization of ferroportin requires binding and cooperative interaction with Jak2. Proceedings of the National Academy of Sciences of the United States of America. 2009;106:3800-3805.

[117] Rivella S. $\beta$-thalassemias: Paradigmatic diseases for scientific discoveries and development of innovative therapies. Haematologica. 2015;100(4):418-430. 
[118] Ganz T. Hepcidin and iron regulation, 10 years later. Blood. 2011;117:4425-4433.

[119] Ganz T, Nemeth E. The hepcidin-ferroportin system as a therapeutic target in anemias and iron overload. Hematology Am Soc Hematol Educ Program. 2011;2011:538542.

[120] Gardenghi S, Ramos P, Marongiu MF, Melchiori L, Breda L, Guy E, Muirhead K, Rao N, Roy CN, Andrews NC, Nemeth E, Follenzi A, An X, Mohandas N, Ginzburg Y, Rachmilewitz EA, Giardina PJ, Grady RW, Rivella S. Hepcidin as a therapeutic tool to limit iron overload and improve anemia in $\beta$-thalassemic mice. J Clin Invest. 2010;120:4466-4477.

[121] Preza GC, Ruchala P, Pinon R, Ramos E, Quiao B, Peralta MA, Sharma S, waring A, Ganz T, Nemeth E. Minihepcidin are rationally designed small peptides that mimic hepcidin activity in mice and may be useful for the treatment of iron overload. J Clin Invest. 2011;121:4880-4888.

[122] Bartnikas TB, Fleming MD. A tincture of hepcidin cures all: The potential for hepcidin therapeutics. J Clin Invest. 2010;120:4187-4190.

[123] Bank A. Regulation of human fetal hemoglobin: New player, new complexities. Blood. 2006;107:435-443.

[124] Gabbianelli M, Morsilli O, Massa A, Pasquini L, Cianciulli P, Testa U, Peschle C. Effective erythropoiesis and $\mathrm{HbF}$ reactivation induced by kit ligand in beta-thalassemia. Blood. 2008;11:421-429.

[125] Aerbajinai W, Zhu J, Gao Z, Chin K, Rodgers GP. Thalidomide induces gamma-globin gene expression through increased reactive oxygen species-mediated p38 MAPK signaling and histone H4 acetylation in adult erythropoiesis. Blood. 2007;110:28642871.

[126] Ginzburg Y, Rivella S. $\beta$-thalassemia: A model for elucidating the dynamic regulation of ineffective erythropoiesis and iron metabolism. Blood. 2011;118:4321-4330.

[127] Wilber A, Nienhuis AW, Persons DA. Transcriptional regulation of fetal to adult hemoglobin switching: A new therapeutic opportunities. Blood. 2011;117: 3945-3953. 